DOI: $10.17951 /$ rh.2018.46.421-432

\author{
Artur Górak \\ (Uniwersytet Marii Curie-Skłodowskiej w Lublinie) \\ https://orcid.org/0000-0002-1964-9008
}

\title{
Modernizacja poprzez kolonizację i wynarodowienie. Uwagi o pracy Malte Rolfa pt. Rzqqdy imperialne w Kraju Nadwiślańskim. Królestwo Polskie i cesarstwo rosyjskie, przekł. Wojciech Włoskowicz, Warszawa 2016, Wydawnictwo Uniwersytetu Warszawskiego, ss. 505
}

Modernization Through Colonization and Denationalization. Remarks on the Book of Malte Rolf, "Rzq̨dy imperialne w Kraju Nadwiślańskim. Królestwo Polskie i cesarstwo rosyjskie", transl. Wojciech Włoskowicz, Warsaw 2016, University of Warsaw Press, pp. 505

W artykule opisano i zanalizowano polskojęzyczne wydanie pracy niemieckiego historyka Malte Rolfa pt. Rządy imperialne w Kraju Nadwiślańskim. Królestwo Polskie i cesarstwo rosyjskie. Autor konfrontuje warstwę faktograficzną książki ze stanem badań i odnosi się do przedstawionych interpretacji. Zwraca uwagę na zdawkowe potraktowanie obecności urzędników, żołnierzy i duchownych rosyjskich w Królestwie oraz polityki oświatowej, a także na całkowite pominięcie likwidacji Kościoła greckokatolickiego i jej następstw.

Słowa kluczowe: Imperium Rosyjskie, Królestwo Polskie, rusyfikacja, kolonizacja, depolonizacja, Warszawa, Malte Rolf

Trzy lata temu w Monachium ukazała się publikacja Malte Rolfa ${ }^{1}$ pt. Imperiale Herrschaft im Weichselland. Das Königreich Polen im Russischen Imperium (1864-1915). Wydanie niemieckie spotkało się z bar-

1 M. Rolf, Imperiale Herrschaft im Weichselland. Das Königreich Polen im Russischen Imperium (1864-1915), München 2015. 
dzo pozytywnym odzewem². Rok później książkę wydano w wersji polskojęzycznej. Treść tych publikacji nie pokrywa się jednak zupełnie. Naszym zadaniem nie jest tu recenzowanie wydania skierowanego do niemieckiego czytelnika ani dokładniejsze porównywanie i ocenianie różnic między obu edycjami, jednak trzeba wspomnieć, że w wersji niemieckiej bardziej rozbudowany był wątek ludności żydowskiej w Królestwie ${ }^{3}$.

Spojrzenie niemieckiego historyka na historię Polski, szczególnie $\mathrm{w}$ aspekcie przedmiotu polityki imperialnej, już samo w sobie jest warte uwagi, a dodatkowym impulsem do zainteresowania się książką było spotkanie z Autorem zorganizowane przez Zakład Historii Idei i Dziejów Inteligencji IH PAN 9 lutego $2018 \mathrm{r}$.

\section{STRUKTURA PRACY}

Praca składa się z siedmiu części podzielonych na mniejsze, niektóre wyróżnione pogrubioną czcionką w spisie treści. Część pierwszą zatytułowaną Wprowadzenie, otwiera opis nieudanego fetowania otwarcia mostu w Warszawie w 1913 r., następnie Autor przedstawia kolejne części pracy. Odrębnie omawia „pojęcia, koncepcje i konteksty dyskusji”.

Obszerną część drugą (Struktury, aktorzy, obszary imperialnego panowania w Królestwie Polskim) rozpoczyna geneza obejmująca lata 1772-1863, a dalej Autor opisuje niektóre aspekty działania administracji rosyjskiej, sylwetki generałów-gubernatorów, cenzurę oraz walkę z katolicyzmem, co rozumie jako „upolitycznienie religii”.

Malte Rolf twierdzi m.in., że katolicy stanowili większość urzędników Królestwa. Nie podaje jednak struktury hierarchicznej, natomiast jest ona znacząca i jednoznaczna zarazem - elity biurokratyczne w całości mieściły się w pojęciu „чиновник русского происхождения”, a do końca lat osiemdziesiątych XIX stulecia zdepolonizowano także prawie wszystkie etaty średniego szczebla. Na tym wszakże nie poprzestano trzecia fala rusyfikacji miała miejsce już w wieku XX, kiedy zdecydowanie wzrosła liczba rosyjskich urzędników nawet na niższych posadach. Imperium doczekało się owoców polityki kolonialnej w postaci urodzo-

2 T.R. Weeks, Book Reviews, „The Russian Review” 2015, 74, 4; D. Staliunas, „Kritika: Poszukiwania w Historii Rosyjskiej i Euroazjatyckiej" jesień 2016, 17, 4, s. 909-917.

3 W polskojęzycznym wydaniu wręcz razi słaba jakość tłumaczenia. Na błędy językowe zwracała też uwage prof. Joanna Schiller-Walicka (Rezension zu: Malte Rolf: Rzady imperialne w Kraju Nadwiślańskim. Królestwo Polskie i cesarstwo rosyjskie 1864-1915, https:// www.pol-int.org/de/node/5585\#r5703) [dostęp: 30 IX 2018]). 
nych w Królestwie Rosjan, zrusyfikowanych Unitów, emerytowanych żołnierzy itd. ${ }^{4}$

Podrozdział zatytułowany Stużba w obcym kraju. Autoidentyfikacja imperialnych kadr urzędniczych w Królestwie Polskim budzi nadzieje na charakterystykę postaw rzeszy rosyjskiej społeczności urzędniczej w Królestwie. Jednakże po lekturze tych 12 stron pozostaje niedosyt. Znajdziemy tam głównie rozważania Autora o stosunku dygnitarzy rosyjskich do słowa rusyfikacja. Dodajmy, że są one wyrwane z kontekstu, przede wszystkim pochodzą z różnych okresów w polityce Imperium wobec Królestwa Polskiego. Autor przedstawia jedynie sylwetki generałów-gubernatorów, pomijając gubernatorów i naczelników innych organów administracji rosyjskiej, nie mówiąc o sądownictwie czy armii. O szeregowych rosyjskich urzędnikach, wojskowych i duchownych z rodzinami nie dowiemy się prawie nic. $\mathrm{W}$ takiej optyce rzeczywiście może zniknąć aspekt kolonizacyjny.

Dodajmy, że Autor błędnie interpretuje słowo $\mathrm{kraj}^{5}$. Nie świadczy ono o odrębności, ale wręcz przeciwnie - wpisuje się w ogólnorosyjską nomenklaturę. Co więcej, jest świadectwem asymilacyjnego podejścia do danego terytorium. To właśnie imperialne (kolonialne) podejście odrzuca historycznie ukształtowane nazwy i wprowadza nowe, najczęściej nawiązujące do obojętnych kulturowo nazw geograficznych: Kraj Nadwiślański, Kraj Nadrioński (Gruzja).

Jedna trzecia książki poświęcona jest Warszawie (część trzecia i czwarta). Jest to zdecydowanie „okręt flagowy” tej pracy. W kwestii oceny aspektów urbanizacyjnych odsyłamy do recenzji autorstwa prof. Agnieszki Zabłockiej-Kos ${ }^{6}$. Dodatkowego omówienia wymaga jednak zauważalna niespójność interpretacyjna. Z jednej strony Autor unika, a wręcz odrzuca spojrzenie na Królestwo Polskie jak na kolonię, a z drugiej strony uwypukla elementy składowe takiego podejścia. Szczególnie widać to w częściach poświęconych Warszawie zamienianej w miasto rosyjskie i miasto dla Rosjan, co jest określane wartościująco - modernizacją. Szkoda, że Autor nie zauwa-

4 Zob. A. Горак, Демократизации доступа к государственной службе - орудие мобилизации русского населения Аюблинской губернии (вторая половина XIX - начало XX 66.), w: Російська імперія у XIX - на початку XX сm. Влада і суспільство: механізми взаємодії: збірник наукових статей, ред. О. Стрілюк, О. Приходьон; автори передмови К. Ячменіхін, Л. Сеніна, Чернігів 2014, s. 376-391.

5 M. Rolf, Rządy imperialne w Kraju Nadwiślańskim. Królestwo Polskie i cesarstwo rosyjskie, przekł. W. Włoskowicz, Warszawa 2016, s. 123.

6 A. Zabłocka-Kos, Obca władza. O Rosjanach w Królestwie Polskim. Omówienie ksiażki: Malte Rolf, Imperiale Herrschaft im Weichselland. Das Königreich Polen im Russischen Imperium (1864-1915), De Gruyter Verlag Oldenbourg, München 2015, 531 ss., 31 il. Seria „Ordnungssysteme. Studien zur Ideengeschichte der Neuzeit", Hrsg. J. Baberowski, A. Doering-Manteuffel, L. Raphael, Bd. 43, "Quart” 2015, 1 (35), s. 75-78. 
ża, iż owa modernizacja stolicy rosyjskich władz miała dla Imperium sens tylko w aspekcie kolonizacji i rusyfikacji. Przerośnięte studium przypadku, jak z pewną przesadą można nazwać te rozdziały książki, zostało umieszczone w próżni. Oczywiście kontekst w postaci urbanizacji Królestwa Polskiego można uznać za nieadekwatny, jednak dojmujący jest brak porównań do Łodzi, która podobnie jak Warszawa zaliczana była do pierwszej szóstki największych miast Imperium Rosyjskiego. Niezwykle przydatne byłyby tu także porównania do Tbilisi czy Poznania.

W czwartej części publikacji znalazły się też fragmenty poświęcone rosyjskiemu Cesarskiemu Uniwersytetowi Warszawskiemu. I tutaj Autor przyjmuje imperialny punkt widzenia, jakby bez zrozumienia relacjonując negatywny stosunek polskich warstw oświeconych do uniwersytetu. Szkoda, że w tej części pracy zabrakło kontekstu w postaci dziejów szkolnictwa Królestwa Polskiego, co musiałoby zmienić optykę pracy ${ }^{7}$.

Kolejna część książki poświęcona jest rewolucji 1905 r. oraz okresowi do wybuchu Wielkiej Wojny.

Podsumowaniem pracy jest część szósta pt. Królestwo Polskie i imperium rosyjskie (pisane małymi literami). Uwagi końcowe, składająca się z dwóch esejów: Kraj Nadwiślański pod petersburskim panowaniem i Kraj Nadwiślański. Królestwo w Cesarstwie. Są to zdecydowanie najlepsze fragmenty recenzowanej publikacji. Autor dobrze relacjonuje obowiązujące w literaturze przedmiotu konstatacje bez ryzykownych reinterpretacji, z którymi można się spotkać w analitycznych częściach książki.

Jeśli jednak szukać nowego podejścia, to uwidacznia się ono w dwóch aspektach. Po pierwsze, książka w większej mierze, niż to się zwykło spotykać w polskich opracowaniach, przyjmuje petersburski (imperialny) punkt widzenia. Wprowadzenie takiej optyki do polskiej historiografii jest pożyteczne nie tylko jako kontrapunkt, ale i dla zachowania równowagi. Po drugie, Autor bardzo umiejętnie pokazuje spektrum postaw wobec rosyjskiego panowania nad Wisła, czasem wręcz przekornie odwracając dotychczasowe oceny. Najlepiej to widać w pozytywnym stosunku do modernizacji Warszawy, jako do wartości samej w sobie, bez uwypuklania kontekstu, a przecież modernizacja ta miała służyć adaptacji miasta do potrzeb rosyjskiej elity. Na pewno nie można się zgodzić z opinia, że „Pogląd Malte Rolfa na rosyjskich władców w Polsce jest odświeżająco bezstronny"8.

7 Por.: D. Szewczuk, Chełmska Dyrekcja Naukowa, Lublin 2012; L. Szymański, Zarys polityki caratu wobec szkolnictwa ogólnokształcacego w Królestwie Polskim w latach 1815-1915, Wrocław 1983.

8 F. Golczewski, Rezension zu: Rolf, Malte: Imperiale Herrschaft im Weichselland. Das Königreich Polen im Russischen Imperium 1864-1915. Berlin 2015, „H-Soz-Kult” 26 XI 2015, www.hsozkult.de/publicationreview/id/rezbuecher-23745 [dostęp: 30 IX 2018]. 
Publikację kończą podziękowania, spis ilustracji, bibliografia i indeks osób połączone w część siódmą zatytułowaną Dodatek. Dodano też wybór [sic!] polskiej literatury tematu. Niektóre błędy w opisach bibliograficznych i braki w wykorzystaniu polskiego stanu badań zostały już zauważone ${ }^{9}$, a jest ich tam zdecydowanie więcej. Jednak to nie wybiórcze zestawienie bibliografii jest znaczące. Nawet prace przytaczane w książce są raczej podawane jako przykłady opracowań na dany temat, bowiem nie widać, aby Autor z ich ustaleń korzystał czy z nimi wprost polemizował.

\section{IMPERIALNE PANOWANIE}

Skoro omawiana publikacja nie jest synteza, to właściwie z czym mamy do czynienia? Autor określa przedmiot pracy jako „imperialne elity Cesarstwa Rosyjskiego i jego zachodniej rubieży - Królestwa Polskiego". Jednak w praktyce ogranicza się do namiestników i generałów-gubernatorów Królestwa Polskiego. A zatem deklaracje Autora są nazbyt obiecujące w tym względzie.

Dalej Malte Rolf deklaruje zakres badania tego przedmiotu jako „zrelacjonowanie rozważań obecnych w licznych debatach prowadzonych nad istotą imperium [...]". Od razu podważa hierarchiczne zróżnicowanie metropolii i prowincji, a także "jednoznaczność projektu kolonialnego". $Z$ drugiej strony sam uwypukla "formatywny wymiar imperium”. Tak więc wiele sprowadza się do gry słów. Jakoby nowatorskie spojrzenie na Królestwo, a szczególnie na Warszawę, przez szermowanie pojęciem „,kolonialna nowoczesność" jest de facto tą samą rusyfikacją i kolonizacją którą znamy z dotychczasowych ujęć problemu. Planowa transformacja kolonii w zrusyfikowaną i zunifikowaną prowincję nie oznacza upodmiotowienia (kulturowego, ekonomicznego i politycznego) rdzennej ludności, a tylko to mogłoby zaprzeczyć podejściu kolonialnemu czy rusyfikacyjnemu. Kolonializm nie definiuje misja cywilizacyjna (choć i tu występuje w postaci rusyfikacji, szczególnie włościan), ale stosunki ekonomiczne, a ostatecznie kolonizowanie danego terytorium.

9 „Autor niewątpliwie zna polskie opracowania i korzysta z nich obficie, jest jednak już utrwalona, a bardzo niedobrą praktyką zachodniej nauki (może wynikającą z presji tamtejszych wydawnictw?) niebranie pod uwagę tej literatury w rzetelnym skądinąd aparacie naukowym. Są to swego rodzaju «postimperialne» działania, które nie powinny mieć miejsca w trakcie uczciwej aktywności akademickiej”. „Przy wielu tematach, zwłaszcza dotyczących Warszawy, dotkliwie jednak odczuwa się brak recepcji ówczesnej prasy polskojęzycznej". A. Zabłocka-Kos, op. cit., s. 76. 
Misja cywilizacyjna, której brakuje Autorowi do spełnienia warunków kolonialnego stosunku Petersburga do Królestwa Polskiego, jest w kilku aspektach widoczna dobitnie, m.in. w polityce oświatowej. Upraszczając, można przecież podsumować, że Petersburg zlikwidował miejscowe szkolnictwo wyższe i mocno zredukował średnie, aby w drugiej połowie wieku „nadać” rosyjski uniwersytet i rozbudować sieć rosyjskojęzycznych szkół ludowych.

Autor świadomie przeciwstawia imperializm (imperialne panowanie) nacjonalizmowi, aby na tym uproszczonym dychotomicznym modelu budować interpretacje wartościujące. Jest to zabieg w historii politycznej i historiografii nie tylko nienowy, ale wręcz archaiczny. Rosyjska literatura polityczna lubuje się w usprawiedliwianiu polityki imperialnej walką ze „złymi” nacjonalizmami. Jednak, nawet przyjmując tę płaszczyznę rozważań, można odwrócić bieguny i rozpatrywać powyższą interakcję jako ścieranie się nacjonalizmu rosyjskiego z ideami wielonarodowej Rzeczypospolitej. Dodajmy, że także braki w analizie charakteru Imperium i stosunku do polskiej kolonii zostały już zauważone ${ }^{10}$.

\section{BRAKUJĄCE ELEMENTY}

Autor nie przywiązuje znaczenia do ekonomii i polityki gospodarczej prowadzonej przez Imperium w Królestwie i w stosunku do niego. A przecież polityka ta nosiła wyraźnie znamiona podejścia kolonialnego, eksploatacji i fiskalizmu. Dodajmy, że lekceważenie polityki ekonomicznej jest już dla tego okresu poważnym zaniedbaniem. W skali całego Imperium, od pierwszej do drugiej połowy XIX w., centrum władzy przesunęło się z ministerstwa spraw wewnętrznych do ministerstwa finansów i innych resortów gospodarczych. Widać to także w Królestwie, gdzie coraz to nowe struktury administracji specjalnej uniezależniały się od gubernatorów. Przy czym rozwój ekonomiczny nie był zasługą aktywnego zarządzania przez Imperium, ale wykorzystania przez przedsiębiorców w Królestwie warunków stworzonych za czasów autonomii lub nieoczekiwanych skutków unifikacji (zniesienie granicy celnej). Notabene z koniunktury gospodarczej Królestwa korzystali przedsiębiorcy różnych narodowości: poza Żydami - Niemcy, Rosjanie, a także Polacy.

Przeniesienie punktu ciężkości z panowania militarnego i politycznego na wyzysk ekonomiczny doskonale mieści się w optyce stosunków kolonialnych. Warto zwrócić uwagę choćby na monografię Jekatieriny

${ }^{10}$ J. Schiller-Walicka, op. cit. 
Prawiłowoj z 2006 r. ${ }^{11}$, która potrafiła wykorzystać nie tylko publicystykę i literaturę z kilku krajów, ale także sięgnąć do źródeł archiwalnych. Mimo stosowania przez interlokutorów różnych metodyk liczenia obciążeń można się zgodzić z twierdzeniem, że „население польских губерний страдало от весьма тяжелого налогового гнета: по сравнению с центральными губерниями, где на одного жителя приходилось 6 руб. 32 коп. сборов, жители польских областей уплачивали 14 руб. 26 коп"12. Za J. Prawiłową dodajmy jeszcze, że w 1907 r. komisja budżetowa II Dumy uznała, że „polskie gubernie” przynosiły 39\% podatku ziemskiego w Imperium ${ }^{13}$. Co więcej, Imperium nakładało też na Królestwo obowiązek utrzymywania swojej armii i administracji, a w obu tych przypadkach były to narzędzia opresji o znacznie większym rozmiarze niż w guberniach wewnętrznych. Owe, podnoszone przez Autora, przykłady modernizacji albo miały służyć militarnym interesom Rosji, albo oznaczały przejście do kolejnego etapu panowania - przygotowania terytorium do kolonizacji. Stopniowe rozszerzanie się obszaru tzw. guberni wewnętrznych, które tak obrazowo przedstawia w swoich pracach japoński uczony Kimitaka Matsuzato ${ }^{14}$, trafnie oddaje przemiany centrum do peryferii: namiestnictwo - generał-gubernatorstwo - gubernia rosyjska. Jeśli Autor właśnie tak rozumie podnoszone przez niego „imperialne formatowanie", to nie wyraża tego wprost.

Totalne prześladowanie kultury polskiej jest w książce Malte Rolfa co najmniej bagatelizowane. Nie da się ukryć pod wytrychem „partnerstwa konfliktu" niszczenia rodzimej kultury (likwidacja szkolnictwa, cenzura, blokowanie inicjatyw społecznych). Szczególnej reinterpretacji Autor poddał walkę z Kościołem katolickim - rozbijanie jedności, hamowanie rozwoju, prześladowania przez administrację. Autor wydaje się nie rozumieć, że religia, a szczególnie Kościół jest podstawowym elementem kultury. Relatywizowanie ocen polityki „carosławia” musi prowadzić na manowce.

11 Е. Правилова, Финансы Илперии. Деньги и власть в политике России на национальных окраинах. 1801-1917, Москва 2006. Szczególnie rozdział 9: Польский взнос в имперскую казну, s. 165-200.

12 Ibidem, s. 185.

13 Ibidem, s. 186.

14 M.in. К. Мацузато, Генерал-губернаторства в российской империи: от этнического $\kappa$ пространственному подходу, w: Новая имперская история постсоветского пространства, ред. И. Герасимов еt al., Казань 2004; idem, Вьлвигая периферию на Восток: территориальная реформа и социальная трансформация в «Большом Оренбуржье» в середине XIX в., w: Региональное управление и проблема эффективности власти в России (XVIII - начало XXI в.), Оренбург 2012, s. 52-53. 
Zupełnie niewytłumaczalne jest pominięcie milczeniem kwestii likwidacji Kościoła greckokatolickiego i prześladowania unitów ${ }^{15}$. Jest to jeden z koronnych projektów rusyfikacyjnych, mających prowadzić do przekształcenia Królestwa Polskiego w rosyjski Nadwiślański Kraj. Akcentowana przez Autora "obcość" tego terytorium nie była tolerowana, a wręcz odwrotnie - Imperium traciło wiele sił i środków na niszczenie rodzimej kultury. Przemilczenie kwestii unickiej i marginalizacja wydzielenia Chełmszczyzny wydaje się zabiegiem celowym, ponieważ pozwala Autorowi na bardziej swobodne interpretacje. Niezwykle w tym kontekście brzmi podziękowanie złożone przez Malte Rolfa dr. Andrzejowi Szabaciukowi ${ }^{16}$.

Innym poważnym pominięciem są opis, rola i wszechstronne znaczenie armii rosyjskiej i to nie tylko stacjonującej w Królestwie, co przecież było niezwykle ważne pod względem politycznym i społecznym - m.in. rozwój infrastruktury komunikacyjnej zachodził pod kątem wymagań strategicznych a nie gospodarczych. Autor nie dostrzega też roli służby wojskowej mieszkańców Królestwa odbywanej w Imperium w „imperialnym formatowaniu” ${ }^{\prime 17}$.

\section{PARTNERSTWO KONFLIKTU}

Malte Rolf pisze o ponadnarodowym charakterze władz imperialnych w Królestwie. W rzeczywistości mamy do czynienia z dwiema metodami (konserwatyści i liberałowie) prowadzącymi do tego samego celu - trwałego podporządkowania terytorium Rosji, a więc rusyfikacji. Szczególnie dobitnie widać to właśnie $\mathrm{w}$ drugiej połowie wieku, gdy pozory imperium universale ustępują nacjonalizmowi rosyjskiemu w różnych odcieniach od imperialnego do ludowego. Różnorodne pochodzenie etniczne elity biurokratycznej przedstawiane jest jako wieloetniczność czy wręcz właśnie ponadnarodowość panowania. To nieporozumienie - wszyscy dygnitarze realizowali russkoje dieło. Pochodzenie od Niemców bałtyckich, Tatarów,

15 J. Lewandowski, Na pograniczu. Polityka władz państwowych wobec unitów Podlasia i Chetmszczyzny 1772-1875, Lublin 1996.

16 A. Szabaciuk, Rosyjski Ulster. Kwestia chetmska w polityce imperialnej Rosji w latach 1863-1915, Lublin 2013.

17 J. Legieć, Stużba rekrutów z Królestwa Polskiego w armii rosyjskiej w latach 1874-1913, Kielce 2013; Я. Легець, Новобранцьь из Царства Польского в войсках Варшавского военного округа, w: Военная история России XIX-XX веков, ред. А.В. Аранович, Санкт-Петербург 2010, s. 53-60; J. Legieć, Polscy rekruci w armii rosyjskiej w latach 1874-1913 - liczebność i rozmieszczenie, „Wrocławskie Studia Wschodnie” 2010, 14, s. 9-26; idem, Powszechny obowiazek stużby wojskowej w armii carskiej jako element polityki rusyfikacyjnej w Królestwie Polskim, w: Między irredenta a kolaboracją. Postawy społeczeństwa polskiego w latach niewoli, red. L. Michalska-Bracha, M. Korybut-Marciniak, Warszawa 2013, s. 151-166. 
starszyzny Hetmanatu czy nawet szlachty Rzeczypospolitej nie miało i nie mogło mieć znaczenia. Co najwyżej można dywagować, czy dany dygnitarz przykładał się do sprawy z przekonania, czy z obowiązku. Zasadniczym elementem ocen rosyjskich czynowników nad Wisłą było oddanie sprawie. Nie przypadkiem za najbrutalniejszych Polakożerców uważa się Teodora Berga i Iosifa Hurko, którzy etnicznymi Rosjanami nie byli.

W ostatniej części Autor bardzo trafnie wyczuwa rezygnację Imperium $\mathrm{z}$ frontalnej rusyfikacji polskości. Integracja, o której tak często pisze, skończyła się, zanim się zaczęła z powodu niewprowadzenia głównych rosyjskich reform, a to one ukształtowały rosyjską rzeczywistość przełomu wieków. Królestwo zostało cofnięte do systemu w Rosji już nieistniejącego. Gubernatorzy rządzili nad Wisłą tak, jak w Rosji przed reformami ${ }^{18}$. Autor odtwarza procesy rozwijające się $\mathrm{w}$ reakcji na tępą negację rodzimej kultury i prześladowania, m.in. w sferze wolnych zawodów, co odcisnęło swoje piętno na charakterze inteligencji polskiej.

Na uznanie zasługuje, bardziej wyczuwany niż wyraźnie deklarowany, opisany nurt kolaboracyjny w społeczeństwie Królestwa i kompletne niezrozumienie oraz niewykorzystanie tej szansy przez biurokrację rosyjską do zaprzęgnięcia polskości do machiny imperialnej, tak jak to się stało z Niemcami bałtyckimi ${ }^{19}$.

W trakcie wspomnianej dyskusji nad książką uczestnicy kilkukrotnie podnosili nowatorstwo pracy Malte Rolfa. Sam Autor, być może jedynie przez skromność, nie podtrzymał jednak tych opinii. Uważam, że pod tym względem trafnie oceniła recenzowaną publikację Joanna Schiller-Walicka: „W sferze czysto faktograficznej książka Rolfa nie wnosi nowych ustaleń - zdecydowana większość informacji w niej zawartych jest już historykom znana [...], a ustalenia własne Autora nie przynoszą w tej kwestii istotnych nowości $[\ldots]^{\prime 20}$. Mimo to można się zgodzić, że praca Malte Rolfa jest próbą reinterpretacji oceny polityki władz Imperium Rosyjskiego w Królestwie Polskim w wybranych przez Autora aspektach.

\section{LABORATORIUM I ŹRÓDŁO INSPIRACJI}

Autor pisze, że Królestwo Polskie było obszarem testowania metod panowania nad obcą etnicznie prowincją. Jednakże nie był to pierwszy poligon formowania takich doświadczeń, ale już co najmniej drugi. Owe me-

\footnotetext{
18 M. Rolf, Rzady imperialne, s. 432.

19 Ibidem, s. 423.

${ }^{20}$ J. Schiller-Walicka, op. cit.
} 
tody w odniesieniu do społeczeństw z tradycją państwową wypracowano już bowiem w Gruzji i jako gotowe zastosowano w Królestwie Polskim po upadku powstania styczniowego.

Jak wiadomo, początkowo (do powstania listopadowego) zabór rosyjski był zarządzany przez miejscowe elity. Zupełnie inną koncepcję zastosowano w Gruzji. Anektowanym Królestwem Kartlii i Kachetii zdecydowano się rządzić inaczej - przy pomocy administracji rosyjskiej, a jedynie z symbolicznym udziałem przedstawicieli miejscowych elit. Było to zdecydowanie inne podejście od zastosowanych do tej pory wobec terytoriów z rozwiniętym systemem prawa, społecznymi i państwowymi strukturami, kulturą. Można tu raczej mówić o adaptacji podejścia dotychczas stosowanego do terytoriów zamieszkanych przez ludy koczownicze, bez państwowości i narodu politycznego. To właśnie dla Gruzji Imperium musiało opracować nowy model panowania, wyobrazić sobie, czym ta prowincja ma być w przyszłości i zrobiło to do początku lat czterdziestych XIX w. ${ }^{21}$ Oczywiście nowa polityka wymagała nowych środków. Nowy model zakładał szybką likwidację odrębności przez ich likwidację lub unifikację oraz nakłonienie ludności do bezwarunkowej kolaboracji z jednoczesnym odsunięciem i izolacją miejscowej elity, która była nosicielem kultury konkurencyjnej do rosyjskiej22.

Inna teza poparta przez Autora jest bardziej uzasadniona - Imperium testowało rozwiązania w Królestwie, które potem wprowadzano w "guberniach wewnętrznych" lub wprost zapożyczano pewne rozwiązania pozostałe po okresie autonomii. Takie zapożyczenia nie są aż tak liczne i świadczą raczej o indywidualnym podejściu określonych dygnitarzy petersburskich. Co do jednego można się zgodzić - analiza rządów imperialnych w Królestwie Polskim pozwala uzyskać gruntowny wgląd w techniki wykorzystywane przez Imperium Rosyjskie przy inkorporacji i transformowaniu obszarów peryferyjnych wobec kultury rosyjskiej.

Jedną z cennych części pracy jest obszerne podsumowanie. Polskiemu czytelnikowi nic szczególnego ono nie przynosi, jednak daje wyobrażenie o tym, jaki przekaz trafił do czytelnika wydania niemieckiego.

21 A. Górak, Ustrój administracji rosyjskiej na Kaukazie (1785-1844), w: Kaukaz w stosunkach międzynarodowych. Przeszłość, teraźniejszość, przyszłość, red. P. Olszewski, K. Borkowski, Piotrków Trybunalski 2008, s. 87-115.

22 А. Горак, Эффективность законодательства о преимуществах чиновников «русского происхождения» в Грузии и Польше, w: Региональное управление и проблема эффективности власти в России (XVIII - начало XXI вв.), ред. Е. Годовова, С. Аюбичанковский, Оренбург 2012, s. 37-48. 
Książka Malte Rolfa nie przybliżyła niemieckiemu czytelnikowi polskiego stanu badań. To nie było jej zadaniem. Niemniej jednak z pewnością zaprezentowała polskim badaczom „imperialne” spojrzenie Autora. Trudno się z nim zgodzić, lecz mieści się ono w granicach dopuszczalnych interpretacji. Należy jedynie mieć nadzieję, że Malte Rolf podejmie się kolejnego wydania publikacji, w którym dookreśli brakujące obszary rosyjskiego panowania.

\section{BIBLIOGRAFIA (REFERENCES)}

Golczewski F., Rezension zu: Rolf, Malte: Imperiale Herrschaft im Weichselland. Das Königreich Polen im Russischen Imperium 1864-1915. Berlin 2015, „H-Soz-Kult” 26 XI 2015, www. hsozkult.de/publicationreview/id/rezbuecher-23745 [dostęp: 30 IX 2018].

Gorak A., Demokratizatsiya dostupa k gosudarstvennoj sluzhbe - orudie mobilizatsii russkogo naseleniya Lyublinskoj gubernii (vtoraya polovina XIX - nachalo XX vv.), w: Rosijs'ka imperiya u XIX - na pochatku XX st. Vlada i suspil'stvo: mekhanizmy vzaiemodiï: zbirnyk naukovykh statej, red. O. Striyuk, O. Prikhod'on; avtori peredmovy K. Jachmenikhin, L. Senina, Chernigiv 2014.

Gorak A., Effektivnost' zakonodatel'stva o preimushchestvakh chinovnikov «russkogo proiskhozhdeniya»v Gruzii i Pol'she, w: Regional'noe upravlenie i problema effektivnosti vlasti v Rossii (XVIII - nachalo XXI vv.), red. E. Godovova, S. Lyubichankovskij, Orenburg 2012.

Górak A., Ustrój administracji rosyjskiej na Kaukazie (1785-1844), w: Kaukaz w stosunkach międzynarodowych. Przeszłość, teraźniejszość, przyszłość, red. P. Olszewski, K. Borkowski, Piotrków Trybunalski 2008.

Legets' Ya., Novobrancy iż Tsarstva Pol'skogo v vojskakh Varshavskogo voennogo okruga, w: Voennaya istoriya Rossii XIX-XX vekov, red. A.V. Aranovich, Sankt-Peterburg 2010.

Legieć J., Służba rekrutów z Królestwa Polskiego w armii rosyjskiej w latach 1874-1913, Kielce 2013.

Lewandowski J., Na pograniczu. Polityka władz państwowych wobec unitów Podlasia i Chełmszczyzny 1772-1875, Lublin 1996.

Matsuzato K., General-gubernatorstva v Rossijskoj imperii: ot ètnicheskogo k prostranstvennomu podkhodu, w: Novaya imperskaya istoriya postsovetskogo prostranstva, red. I. Gerasimov et al., Kazan' 2004.

Matsuzato K., Vydvigaya periferiyu na Vostok: territorial'naya reforma o sotsial'naya transformatsiya $v$ «Bol'shom Orenburzh'e» v seredine XIX v., w: Regional'noe upravlenie i problema effektivnosti vlasti v Rossii (XVIII - nachalo XXI v.), Orenburg 2012.

Pravilova E., Finansy Imperii. Den'gi i vlast'v politike Rossii na natsional'nykh okrainakh. 18011917, Moskva 2006.

Rolf M., Imperiale Herrschaft im Weichselland. Das Königreich Polen im Russischen Imperium (1864-1915), München 2015.

Rolf M., Rzady imperialne w Kraju Nadwiślańskim. Królestwo Polskie i cesarstwo rosyjskie, przekł. W. Włoskowicz, Warszawa 2016.

Schiller-Walicka J., Rezension zu: Malte Rolf: Rzady imperialne w Kraju Nadwiślańskim. Królestwo Polskie i cesarstwo rosyjskie 1864-1915, 2016, https://www.pol-int.org/de/node /5585\#r5703 [dostęp: 30 IX 2018].

Staliunas D., „Kritika: Poszukiwania w Historii Rosyjskiej i Euroazjatyckiej” jesień 2016, 17,4 . 
Szabaciuk A., Rosyjski Ulster. Kwestia chetmska w polityce imperialnej Rosji w latach 1863-1915, Lublin 2013.

Szewczuk D., Chetmska Dyrekcja Naukowa, Lublin 2012.

Szymański L., Zarys polityki caratu wobec szkolnictwa ogólnoksztatcacego w Królestwie Polskim w latach 1815-1915, Wrocław 1983.

Weeks T.R., Book Reviews, „The Russian Review” 2015, 74, 4.

Zabłocka-Kos A., Obca władza. O Rosjanach w Królestwie Polskim. Omówienie ksiażki: Malte Rolf, Imperiale Herrschaft im Weichselland. Das Königreich Polen im Russischen Imperium (1864-1915), De Gruyter Verlag Oldenbourg, München 2015, 531 ss., 31 il. Seria „Ordnungssysteme. Studien zur Ideengeschichte der Neuzeit", Hrsg. J. Baberowski, A. Doering-Manteuffel, L. Raphael, Bd. 43, „Quart” 2015, 1 (35).

\begin{abstract}
The article describes and analyses the Polish language edition of the book Rzady imperialne w Kraju Nadwiślańskim. Królestwo Polskie i cesarstwo rosyjskie by the German historian Malte Rolf. The article confronts the factual layer of the book with the state of research and comments on the presented interpretations. The author draws attention to the cursory treatment of the presence of civil servants, soldiers and Russian priests in the Kingdom and the similarly perfunctory presentation of the educational policy, as well as the complete omission of the liquidation of the Greek Catholic Church and its consequences.
\end{abstract}

Key words: Russian Empire, Polish Kingdom, russification, colonization, depolonization, Warsaw, Malte Rolf

\title{
NOTA O AUTORZE
}

Artur Górak - doktor habilitowany, adiunkt w Zakładzie Archiwistyki i Nauk Pomocniczych Historii Uniwersytetu Marii Curie-Skłodowskiej w Lublinie, prezes Towarzystwa Nauki i Kultury „Libra”. Jego zainteresowania badawcze koncentrują się wokół dziejów biurokracji, archiwistyki i historii Imperium Rosyjskiego. Autor blisko 100 publikacji naukowych w czasopismach krajowych i zagranicznych, a także 10 monografii, m.in.: Kancelaria Gubernatora i Rzad Gubernialny Lubelski (1867-1918). Studium administracyjne i prozopograficzne (Lublin-Radzyń Podlaski 2006); Rosyjska kancelaria akt spraw w urzędach lubelskiej gubernialnej administracji ogólnej w latach 1867-1918 (Lublin 2008); Rosyjska administracja specjalna w Królestwie Polskim, 1839-1918 (współautor Krzysztof Latawiec, Lublin 2014) oraz wielotomowej serii słowników biograficznych gubernatorów, wicegubernatorów i naczelników administracji specjalnej Królestwa Polskiego. Inicjator i redaktor serii wydawniczej „Dzieje Biurokracji” (http://tonik-libra.pl/dzieje-biurokracji/). Redaktor naczelny „Wschodniego Rocznika Humanistycznego" (http://wrh.edu.pl/). E-mail: artur. gorak@umcs.lublin.pl_ 